\title{
Paste technology - not just for mining anymore
}

\author{
Sue Longo Golder Associates Ltd, Canada \\ Paul Pigeon Golder Associates Inc, United States of America \\ Corné Pretorius Golder Associates Ltd, Canada
}

\begin{abstract}
With recent changes in legislation in the United States the EPA (Environmental Protection Agency) has decreed that the disposal and storage of slurried Coal Combustion Residues (CCR) is no longer acceptable. The legislation applies to both legacy as well as active ponds. In addition, the Effluent Limit Guidelines (ELG) also dictates handling, transport and storage requirements for all process-affected water on site for coal fired power plants. These two significant regulatory changes in the industry are driving power companies towards alternate solutions for their waste management. While paste and thickened tailings technology has been widely used in mining applications around the world for more than 20 years it is relatively unknown in the power sector even though several paste plants have been designed, built and are operating.

This paper will describe the issues facing the coal fired power plant industry and how paste and thickened ash is providing an alternative to thermal drying and landfilling options that currently exist. Specifically, test data will be shown that demonstrates the encapsulation of the minerals and metals of concern using paste. The paste recipe was developed to maximize the use of the Flue Gas Desulphurization (FGD) wastewater and other waste and wastewater streams produced in the facility along with the CCR materials available including fly ash and bottom ash.

Case studies will also be presented from South Africa and the US, demonstrating the recipes and process design that can be implemented to solve both the CCR and ELG problems.
\end{abstract}

\section{Introduction}

Recent changes in US legislation, such as the EPA's newly enacted Coal Combustion Residuals (CCR) rules and Effluent Limitations Guidelines (ELG), have motivated the coal-fired power generation industry to explore ways to manage their waste products. Paste technology has been applied to CCR products in the past to manage and stabilize the solid waste by-products but a new application of paste technology is also helping the industry handle the disposal of their waste water as well.

In this paper an introduction to the challenges the power industry is facing will be presented as well as laboratory testing results on the capabilities of CCR paste and its ability to encapsulate metals and other harmful pollutants using the wastewater streams on site.

\section{Coal fired power industry challenges}

Most coal fired power plants have operated for years if not decades using conventional slurry disposal methods where the main coal combustion by-products of fly ash (FA) and/or bottom ash (BA) have been slurried and sent to a pond or impoundment if they could not be sold. In addition to the CCR materials, different wastewater streams that can't be recycled have been co-disposed with the FA and BA in the ponds. 
These wastewater streams have traditionally had potentially problematic levels of metals and other contaminants of concern. In many cases, the disposal ponds were unlined and located near to major surface water bodies and underground aquifers. The combination of these waste materials, the unlined nature of the ponds and the proximity of sensitive environmental receptors has been a concern in the industry for a long time.

The changes in the EPA regulations have forced the power sector to review these practices and take steps to properly monitor the environment for potential contamination and ultimately to close those ponds that pose a potential threat to the environment. For many industry members, an ideal solution would be "walk away closure" of their CCR disposal facilities as opposed to clean closure which involves the removal and relocation of all materials to an appropriate facility. The distance towards this ideal of walk away closure is daunting, given the need for monitoring and management in many current systems. Most critical is the need for a satisfactory solution to minimize leachate and seepage from the disposal areas, restrict or eliminate the use of transport water, and manage the wastewater streams that may carry metals such as selenium and mercury. To achieve these aims there must be a change to the operating practices to avoid slurry disposal going forward. Some facilities had or have been making the change to dry handling of FA and BA which then go to a landfill which alleviates some of the pond issues but the wastewaters streams still exist. So the question remains-what do we do about the wastewater?

The first answer is naturally water treatment. The wastewater streams affected by the ELG regulations are as follows:

- Fly and Bottom Ash Transport Waters.

- FGD, Gasification and FGMC Wastewaters.

- Combustion Residual Leachate.

The primary focus of this paper is the FGD wastewater stream which has strict limits for $\mathrm{As}, \mathrm{Hg}, \mathrm{Se}, \mathrm{NO}_{3}$. Worth noting is notwithstanding the EPA regulations the local Permit Authority can issue limits more stringent than BAT for FGD and other streams which means that any solution must have flexibility and adaptability to answer to local requirements as well as the federal rule.

Water treatment technologies vary from fairly standard physical/chemical treatments that treat the metals and contaminants, allowing the water to be recycled to the plant all the way up to thermal drying or crystallization which concentrates or crystallizes the water into a dry or semi-dry form. In the former technologies sludge from wastewater treatment must be managed as well as the volume of treated water itself whereas in the crystallization process the residuals which are highly soluble must be managed carefully to avoid remobilization post deposition.

The focus of the ELG regulation is on the Best Available Treatment (BAT) for existing generating units and certain associated wastewaters. A non-exhaustive list of wastewater treatment options including the BAT is outlined below:

- BAT-Physical-Chemical plus Biological.

- Physical-Chemical Modifications plus Media Adsorption or Sulfide Precipitation.

- Physical-Chemical Pretreatment with Evaporation.

- Physical-Chemical with Filtration plus Deep Well Injection.

- Thermal drying.

- Crystallization.

- Encapsulation.

Wastewater treatment costs can vary greatly however invariably that cost goes up exponentially as the target concentration increases. Reducing the wastewater constituents to crystalized form is the most costly of all. 
The situation calls for a solution that reduces or avoids the need to move all the way along the concentration curve to crystallization but that also immobilizes the constituents in a way that is reliable long term.

\section{$3 \quad$ How can paste help?}

Paste turns the water 'problem' into part of the solution. One of the attractions of the paste process is that water is required as part of the recipe-and that water can contain contaminants and still do its job. One of the objectives of the paste process in CCR applications is to maximize the use of wastewater-water that would otherwise need to be treated.

Through the paste process, constituents of concern, such as mercury, that are present in the wastewater can be immobilized as well as the ash itself. Even the most problematic constituents in the wastewater can be encapsulated.

It works with dry or wet ash: paste technology can be applied whether any of the three main waste streams (fly ash, bottom ash, FGD) are in dry or wet form. This gives it a flexibility that allows for use across a fleet of coal-fired power stations, or in cases where the process at a plant changes.

It also supports progressive slurry pond closure. The paste mass can be used as a cover system for ash ponds to immobilize the slurry, giving potential for progressive closure of those ponds. This has been applied in a hard-rock mining context, but so far we have not yet used it for CCR. As an extension to closure there is also a potential for beneficial re-use of the property. Once the paste has desiccated or in the case of pozzolanic materials, cured, the surface may be available for alternate end of life uses, such as parkland, wildlife habitat or re-use as industrial or housing property. This can go a long way to building good relations with regulatory authorities and the general public-taking a potential problem and creating beneficial re-use.

\section{$4 \quad$ Current test work results}

In three separate test programs various CCR materials were tested with FGD wastewater brines to make paste. The goal of the paste material is stability-both geotechnical and geochemical. The measures of stability in this context as measured are the paint filter test, hydraulic conductivity, strength as defined by Unconfined Compressive Strength (UCS) tests, acid generating potential.

\subsection{US samples}

In multiple test programs, different CCR samples were received from Coal-Fired Power Plants located in the US. Fly ash, bottom ash and FGD solids samples from each site were tested to determine their blend interaction, dewatering properties, rheology, acid generation and metal leaching potential. (Longo et al., 2016), the traditional paste tests were reported for some of the samples including index testing and rheology however for the purposes of this paper only a few results will be discussed.

\subsubsection{Paint filter test}

The paint filter test is a method approved by EPA to determine the presence of free liquids in a sample of waste. Typical household waste samples in the US must pass this test prior to be discharged in landfills. While passing this test does not necessarily indicate that the CCR can be disposed of, it shows an indication of the capability of the CCR paste to encapsulate water and any other harmful contaminants that could otherwise be released to the environment.

Table 1 shows the results of the paint filter tests performed on a 70\% fly ash and 30\% FGD solids blend sample at different slumps. 
Table 1 Paint filter test results on $\mathbf{7 0 \%}$ fly ash / $30 \%$ fgd solids blend from the southern us

\begin{tabular}{|c|c|c|c|c|}
\hline $\begin{array}{c}\text { Slump } \\
\text { (inches) }\end{array}$ & $\begin{array}{c}\text { Sample Densities } \\
\text { (wt\% solids) }\end{array}$ & Free Liquids Present & Amount of Free Liquid (mL) & Filtrate Discharge Quality \\
\hline $3^{\prime \prime}$ & $80.4 \%$ & No & 0 & $\mathrm{n} / \mathrm{a}$ \\
\hline $5 ”$ & $79.6 \%$ & No & 0 & $\mathrm{n} / \mathrm{a}$ \\
\hline 7" & $78.6 \%$ & No & 0 & $\mathrm{n} / \mathrm{a}$ \\
\hline $10.5^{\prime \prime}$ & $77.8 \%$ & Yes & 1 & dark \\
\hline
\end{tabular}

As seen in Table 1 the 10.5" slump sample did not pass the test, but the 7", 5" and 3" slump samples passed.

Table 2 Paint filter test results on mulitple blends from the mid-west us

\begin{tabular}{|c|c|c|c|c|}
\hline Blend & $\begin{array}{l}\text { Slump } \\
\text { (inches) }\end{array}$ & $\begin{array}{l}\text { Free Liquids } \\
\text { Present } \\
\text { (24 hrs) }\end{array}$ & $\begin{array}{l}\text { Amount of Free } \\
\text { Liquid } \\
\text { (mL) }\end{array}$ & $\begin{array}{c}\text { Filtrate Discharge } \\
\text { Quality }\end{array}$ \\
\hline Blend 1 (Fly Ash) & 10 & No & 0 & $\mathrm{n} / \mathrm{a}$ \\
\hline Blend 2 (Fly Ash / Bottom Ash) & 10 & No & 0 & $\mathrm{n} / \mathrm{a}$ \\
\hline Blend 3 (Ash Sludge / Lime Sludge) & 10 & Yes & 0.07 & dark \\
\hline Blend 4 (Ash Sludge / Fly Ash) & 10 & No & 0 & $\mathrm{n} / \mathrm{a}$ \\
\hline Blend 5 (Fly Ash / Lime Sludge) & 10 & No & 0 & $\mathrm{n} / \mathrm{a}$ \\
\hline Blend 6 (Fly Ash / Gypsum / Bottom Ash) & 10 & No & 0 & $\mathrm{n} / \mathrm{a}$ \\
\hline $\begin{array}{l}\text { Blend 7-Slurry (Fly Ash / Bottom Ash / } \\
\text { Ash Sludge) }\end{array}$ & 10 & No & 0 & $\mathrm{n} / \mathrm{a}$ \\
\hline $\begin{array}{c}\text { Blend } 8 \text { (Fly Ash / Bottom Ash / Ash } \\
\text { Sludge / Retardant) }\end{array}$ & 10 & No & 0 & $\mathrm{n} / \mathrm{a}$ \\
\hline
\end{tabular}

As can be seen in Table 2 only one sample did not pass the paint filter test at a 10" slump.

In both of these test results using different ash and different wastewater brine materials the paste matrix performs very well in passing the paint filter test within $24 \mathrm{~h}$ of being mixed and deposited.

\subsubsection{Hydraulic conductivity}

Hydraulic conductivity provides an indication on how well water can move through the paste. There are three common methods available for determining the percolation rate of a material sample, these are:

- PSD curve analysis.

- Constant head.

- Falling head tests.

For the Southern US sample based on the PSD of the 70\% fly ash / 30\% FGD solids blend the theoretical hydraulic conductivity of the sample is $9.63 \times 10^{-6} \mathrm{~cm} / \mathrm{s}$.

For the Mid-west test blends the results are in Table 3. 
Table 3 Permeability test results from falling head for mid-west us

\begin{tabular}{ccc}
\hline Blend & $\begin{array}{c}\text { Permeability (K) } \\
\text { (inches/sec) }\end{array}$ & Measured Perm. K (cm/sec) \\
\hline Blend 1 (Fly Ash) & $1.75 \mathrm{E}-06$ & $4.45 \mathrm{E}-06$ \\
Blend 2 (Fly Ash / Bottom Ash) & $3.95 \mathrm{E}-06$ & $1.00 \mathrm{E}-05$ \\
Blend 3 (Ash Sludge / Lime Sludge) & $2.80 \mathrm{E}-06$ & $7.12 \mathrm{E}-06$ \\
Blend 4 (Ash Sludge / Fly Ash) & $2.83 \mathrm{E}-06$ & $7.18 \mathrm{E}-06$ \\
Blend 5 (Fly Ash / Lime Sludge) & $3.16 \mathrm{E}-06$ & $8.02 \mathrm{E}-06$ \\
Blend 6 (Fly Ash / Gypsum / Bottom Ash) & $1.91 \mathrm{E}-06$ & $4.85 \mathrm{E}-06$ \\
Blend 7-Slurry (Fly Ash / Bottom Ash / Ash Sludge) & $2.79 \mathrm{E}-06$ & $7.09 \mathrm{E}-06$ \\
Blend 8 (Fly Ash / Bottom Ash / Ash Sludge / Retardant) & $3.15 \mathrm{E}-06$ & $8.81 \mathrm{E}-06$ \\
\hline
\end{tabular}

The results show that all blends have a reasonable low hydraulic conductivity.

The paste matrix has hydraulic conductivities low enough to restrict the flow of water through the material.

\subsubsection{Unconfined compressive strength}

The unconfined compressive strength (UCS) is an important factor in the long term stability of the paste in the deposition area. As well, an indication of strength gain over time is critical for developing deposit management timelines before curing makes it too difficult to change in the deposit. In Figure 1 below the UCS test results show the difference between wastewater brines in the development of strength for a South African power plant (Pretorius, 2011).

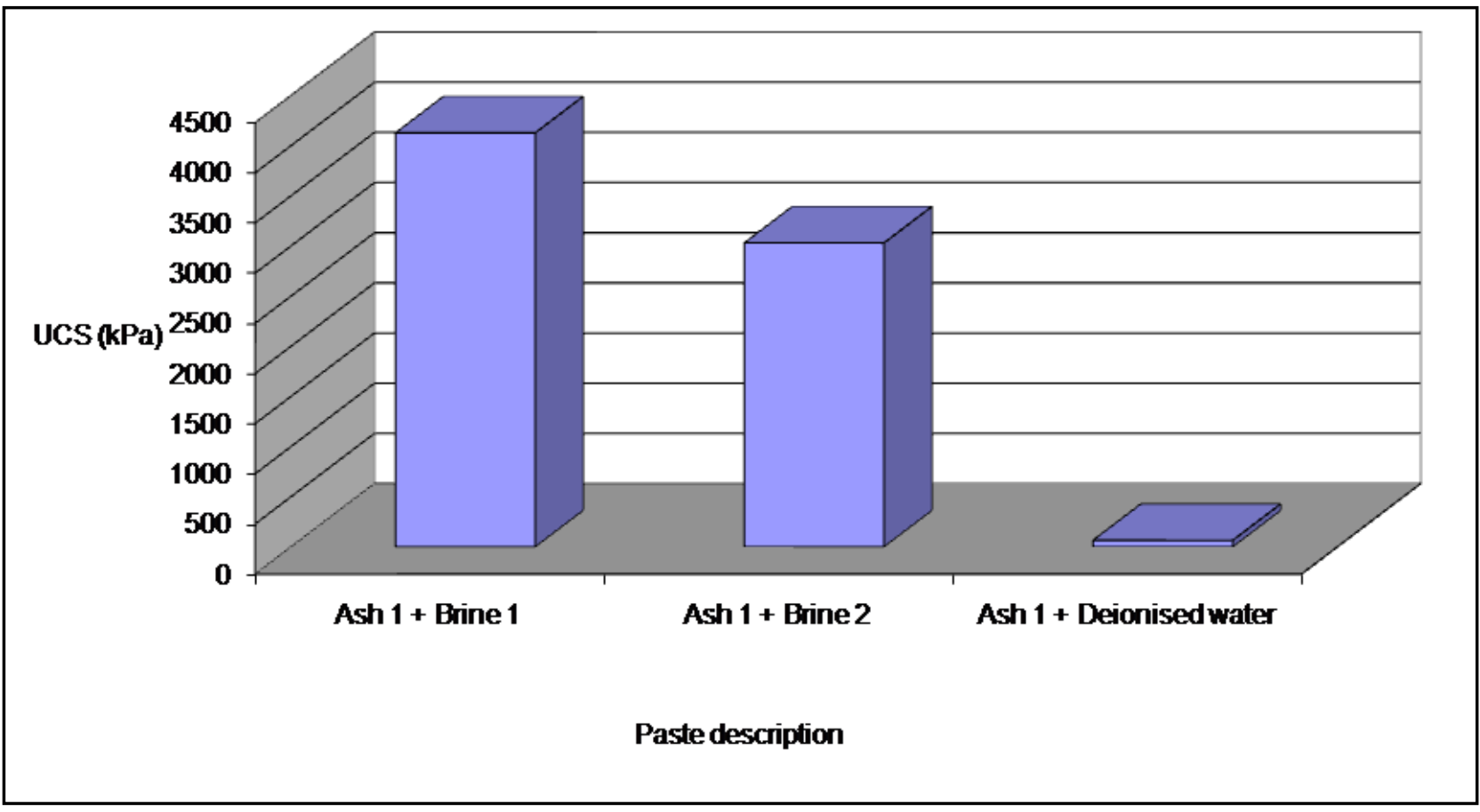

Figure 1 UCS results for a South African fly ash / brine blends

In Table 4, the results of another UCS program are shown. 
Table 4 UCS results for mid-west US blends

\begin{tabular}{cccc}
\hline Blend & Slump & $\begin{array}{c}\text { Average UCS (kPa) } \\
\text { 3 days }\end{array}$ & $\begin{array}{c}\text { Average UCS (kPa) } \\
\text { 7 days }\end{array}$ \\
\hline Blend 1 (Fly Ash) & 10 & 110 & 303 \\
Blend 2 (Fly Ash / Bottom Ash) & 10 & 14 & 110 \\
Blend 3 (Ash Sludge / Lime Sludge) & 10 & Too Soft & Too Soft \\
Blend 4 (Ash Sludge / Fly Ash) & 10 & 14 & 41 \\
Blend 5 (Fly Ash / Lime Sludge) & 10 & 159 & 717 \\
Blend 6 (Fly Ash / Gypsum / Bottom Ash) & 10 & 131 & 269 \\
Blend 7-Slurry (Fly Ash / Bottom Ash / Ash Sludge) & 10 & 7 & 110 \\
Blend 8 (Fly Ash / Bottom Ash / Ash Sludge / Retardant) & 10 & 21 & 145 \\
\hline
\end{tabular}

\subsubsection{Acid generating and metal leaching potential}

A testing campaign, performed on CCR samples collected from a South-Eastern US Coal-Fired Power Plant, assessed the acid generating and metal leaching potential of the CCR paste. For this testing program the paste mixes were prepared as indicated in Table 5.

Table 5 Paste mix design recipes

\begin{tabular}{ccccc}
\hline Paste Mix & $\begin{array}{c}\text { Fly Ash } \\
\text { (\% total mass) }\end{array}$ & $\begin{array}{c}\text { Gypsum } \\
\text { (\% total mass) }\end{array}$ & $\begin{array}{c}\text { Lime } \\
\text { (\% total mass) }\end{array}$ & $\begin{array}{c}\text { FGD Water } \\
\text { (\% total mass) }\end{array}$ \\
\hline Paste Mix \#1 & 58 & 8 & 5 & 30 \\
Paste Mix \#2 & 40 & 25 & 5 & 30 \\
Paste Mix \#3 & 61 & 8 & 0 & 32 \\
Paste Mix \#4 & 42 & 26 & 0 & 32 \\
\hline
\end{tabular}

Several approaches were considered to assess acid generation potential and it was shown that the samples are largely not potentially acid generating. All four paste mixes showed to be enriched (greater than ten times the crustal abundance) in arsenic, sulfur, molybdenum, and selenium.

Water chemistry analyses for FGD water and Paste Mix \#4 water bleed show that the two samples are similar in terms of total dissolved solids, hardness and concentration of the dominant ions (chloride and calcium). The main difference between the FGD water and the Paste Mix \#4 bleed water samples are pH (2.45 versus 8.83 , respectively) and alkalinity (total, $<0.5$ versus 2300 , respectively). These results demonstrate that the paste mix effectively neutralizes the FGD water. Other notable differences between the two water samples include the bleed water from Paste Mix \#4 had lower (by an order of magnitude) cadmium, copper, nickel, uranium and zinc compared to the FGD water, suggesting these constituents are retained in the mixture.

\section{$5 \quad$ Testwork conclusions}

In the key test areas of paint filter, permeability, strength and acid generating potential all the test work to date shows that paste blends using CCR materials and FGD wastewater can produce a paste material with characteristics that meet the requirements of the ELG regulations and avoid going to Zero Liquid Discharge (ZLD) applications like thermal drying and crystallization.

\section{$6 \quad$ Hurdles to overcome in using paste for CCR disposal}

So the testwork confirms that using paste is a potential solution for the Coal Fired Power Plant industry for managing their CCR and ELG regulatory requirements. So why hasn't this technical solution been more widely adopted? 
- Regulatory approval: While US-EPA and other regulatory bodies at federal and state level may be aware of paste technology, it is still a new idea to many officials. This makes it important for any power producer considering paste for CCR applications to work closely with relevant officials on a local basis, introducing them to the idea and explaining how it works. It helps if the power utility has both internal and external resources that are familiar with paste technology and can answer regulators' questions. There are multiple active sites in the US using paste technology both in the power sector as well as the mining sector that are available to visit to demonstrate the plant, system and deposition strategies.

- Defining "solid" versus "liquid": One of the issues yet to be determined is the regulatory approach to whether paste can be defined as a solid or liquid. While it is mixed in the plant to a form that can be pumped through a pipeline, paste cures within hours or days into a solid form that is trafficable and can be vegetated.

- Site-specific variations: No solution is catch-all. This includes paste. Each site and each material is different and should be considered individually. In some cases, such as a power plant that is close to an established landfill, it may be more appropriate to just truck the CCR there for disposal and treat the wastewater streams separately. Paste is one tool in the toolbox of the power plant operator and should be considered in any options assessment. The key is to look at the system holistically and consider the technical, social, environmental and economic factors before making a decision.

\section{$7 \quad$ Conclusions}

Managing coal combustion products in today's environment is challenging to say the least. With the new EPA rules in place technologies must be implemented to manage current operations as well as legacy sites. Paste technology applications have been commonplace in the mining industry for 20+ years to deal with fine waste products but it has taken recent changes in legislation to put paste in the spotlight for the power sector.

The challenge with any new technology application is to balance commercial aspects with technical risk and deliver a solution that meets regulatory requirements at the deposition site. Paste is a proven solution-an engineered solution-that can be designed to deal with each individual waste stream or to manage wastes within a co-disposal framework.

The three sites discussed in the paper have very different characteristics and performance but all of them have proven amenable to a paste solution from the technical perspective. More work needs to be done in the environmental and economic assessments to highlight the ability of paste to fit into the commercial and legal framework of the Coal Fired Power Plants. However the power sector is not the first industry to go through this transition. In the mining industry, surface disposal of high density waste materials is commonplace and the lessons learned in mining can be readily applied to coal combustion products.

\section{$8 \quad$ Acknowledgement}

The author acknowledge the help and support of various Golder Associates colleagues including Paul Pigeon and Corne Pretorius in the preparation and presentation of this paper.

\section{References}

Environmental Protection Agency 2004, 'Test Method 9095B: Paint Filter Liquids Test, part of Test Methods for Evaluating Solid Waste', Physical/Chemical Methods, Revision 2.

Environmental Protection Agency 2015, '40 CFR Part 423 Effluent Limitations Guidelines and Standards for the Steam Electric Power Generating Point Source Category', Final Rule, vol. 80, no. 212, part II.

Longo, S. 2015, 'Paste and Ash Systems: Case Studies', 2015 World of Coal Ash Conference (WOCA). 
Longo, S. Quintero, Andres, Pretorius, P.C. '2016, Paste Application for the Sustainable Management of Coal-Fired Power Plant's Waste', International Water Conference.

Pretorius, P.C., Mahlaba, J.S., Nzotta, U. and Hareeparsad, S. 2011, 'Fundamental research on brine-based fly ash pastes for underground disposal', Minefill 2011-10th International Symposium on Mining with Backfill. 